\title{
РЕОРГАНІЗАЦІЯ СИСТЕМИ ПІДГОТОВКИ НАУКОВИХ КАДРІВ У ДОНЕЦЬКОМУ НАЦІОНАЛЬНОМУ МЕДИЧНОМУ УНІВЕРСИТЕТІ IМ. М. ГОРЬКОГО
}

Донецький національниймедичний університет ім. М. Горького

\section{REORGANIZATION OF ACADEMIC TRAINING SYSTEM IN DONETSK NATIONAL MEDICAL UNIVERSITY BY M. HORKYI}

\author{
Yu. V. Dumanskyi, O. M. Sulaieva, I. I. Zinkovych \\ Donetsk National Medical University by M. Horkyi
}

\begin{abstract}
У роботі обгрунтовусться доцільність та обговорюються шляхи реорганізації системи підготовки наукових та науково-педагогічних кадрів через аспірантуру у Донецькому національному медичному університеті ім. М. Горького. На основі аналізу європейських докторських програм були сформульовані принципи та вимоги до освітньої підготовки в аспірантурі. Згідно з нормативними документами та відповідно до потреб молодих вчених університету було розроблено та впроваджується програма багаторівневої мультидисциплінарної освітньої підготовки аспірантів.
\end{abstract}

Needs and mechanisms of academic training system reorganization are discussed in this article according to the experience and innovations in M. Horkyi Donetsk National Medical University. Based on the analysis of European doctoral programs the principles and requirements for educational training in post-graduate school were grounded. According to the national regularities and on the basis of young scientists survey results has the multidisciplinary educational training of post-graduate students have been developed and implemented in M. Horkyi Donetsk National Medical University.

Вступ. Одним зі стратегічних напрямків науководослідної роботи вузів $€$ реформування системи підготовки науково-педагогічних кадрів [12]. На сьогодні оптимальною формою підготовки наукових кадрів вважається аспірантура, що є третім циклом освіти згідно з Болонською декларацією, до якої України приєдналася у 2005 році. Проте наскільки ця система підготовки наукових кадрів відповідає потребам суспільства, вузів та самих науковців, питання провокаційне. I не стільки 3 політичних чи бюрократичних позицій, скільки 3 можливостей використання цієї системи у якості детермінанти науково-технічного прогресу в цілому. Аналіз європейських програм підготовки наукових кадрів та тенденцій розвитку медичної науки у світі $[3,8,11]$, а також досвід участі Донецького національного медичного університету у конференції ORPHEUS "Establishing Evaluation of PhD Training", 3 одного боку, показав, на скільки кроків вперед просунулася Свропа за останні 7 років [6, 10]. Проте, з іншого боку, вивів наш університет 3 "мертвої зони" несвідомої некомпетентності, стимулювавши до реорганізації системи підготовки наукових кадрів.

У даній роботі ми представляємо власний досвід розробки та впровадження нової системи підготовки наукових кадрів. Ця робота здійснюється з 2010 року за певною схемою, що включає: 1) інформаційний пошук та аналіз існуючих моделей післядипломної освіти в Свропі; 2) порівняння переваг, недоліків та проблем існуючих програм реалізації даного освітньо-наукового рівня; 3 ) детальний аналіз існуючої національної нормативної бази, що регламентує здійснення підготовки наукових кадрів та визначає досі не реалізовані можливості впровадження інновацій у цій галузі; 4) формування власної моделі підготовки науково-педагогічних кадрів.

Основна частина. Аналіз сучасної ситуації у сфері докторських програм дозволив визначити широку різноманітність систем підготовки кадрів у різних країнах та університетах, що пов' язано з історичними традиціями, соціально-економічними, культурними і національними особливостями, системою менеджменту тощо [5, 9]. Варіації докторських програм за структурою включали в першу чергу розбіжності за тривалістю. Загальна тривалість $\mathrm{PhD}$ програм у вузах Європи складає 3 роки - для дослідників, 4 роки - для викладачів. У деяких країнах тривалість аспірантури визначається iii типом: очна (full-time) - 3 роки, заочна (part-time) - 4 роки. Характерно, що в

() Ю. В. Думанський, О. М. Сулаєва, І. І. Зінкович 
більшості країн Свропи докторські програми включають не лише науково-дослідну, але й освітню частини підготовки. Насиченість останньої широко варіює - від 22 до 60 кредитів щороку. Найпоширеніший варіант об'єму освітньої програми складає 30 кредитів на рік, причому навчання відбувається протягом усього терміну $\mathrm{PhD}$ програми [7]. Незалежно від географічних та соціально-економічних умов, зазвичай $\mathrm{PhD}$ програми включають обов'язкову та варіативну частини. Зміст обов'язкової освітньої програми навчання аспірантів уніфікований. Тоді як перелік і структура необов'язкових (варіативних) програм навчання широко варіюють за тематикою, об' ємом і змістом залежно від наукових пріоритетів кожного університету. Характерно, що більшість університетів Свропи мають власні дослідницькі школи (своєрідне наукове обличчя) та реалізують сумісні наукові та освітні програми з іншими закладами Свропи $[1,2,10]$.

Важливо, що й адміністрування $\mathrm{PhD}$ навчання в Європі значно відрізняється від країн пострадянського простору. Особливості цієї сфери в першу чергу пов'язані $з$ кількістю PhD-студентів, яка на медичному факультеті середнього європейського університету складає від 300 до 500 осіб. Така вражаюча кількість $\mathrm{PhD}$-студентів враховує бюджетні та контракті форми навчання аспірантів i, з одного боку, демонструє високий попит на виконання наукових досліджень. 3 іншого боку, цей факт має просте пояснення. У Свропі не існує іншого варіанта отримання звання $\mathrm{PhD}$, як через проходження освітньої програми та контролю якості виконуваного наукового дослідження. Звісно, що за великої кількості $\mathrm{PhD}$ кандидатів в університетах Свропи функціонують окремі адміністративні підрозділи з широкою мережею координаторів, які розробляють та індивідуалізують програму навчання аспірантів залежно від тематики наукового проекту, забезпечують поточний контроль і корекцію освітньої траєкторії, та є посередниками між аспірантами і програмами навчання [4].

Особливої уваги заслуговує й питання щодо оцінки у європейських університетах ефективності $\mathrm{PhD}$-програм, яка проводиться на внутрішньоуніверситетському, національному та інтернаціональному рівнях [10, 12]. Надзвичайно, що за показниками результативності, лише до 80 \% PhD-студентів повністю завершують навчання за докторськими програмами, i лише від 60-84 \% 3 них проходять публічний захист дисертаційного дослідження. I це не вважається за проблему, оскільки кінцевою метою докторської програми є набуття освітньо-наукового рівня. Незважа- ючи на різноманіття тривалості, структури та змісту, всі докторські програми побудовані за певними принципами $[1,2]$, які включають:

1. Спрямованість на стимуляцію оригінальних наукових досліджень 3 високим рівнем новизни та значущості, з акцентом на фундаментальні дослідження та отримання нових знань. При цьому нівелюється система академічних стандартів, навпаки перевага віддається формуванню нових ідей, розвитку творчості та інновацій, які визначають можливість розширення сфери знань та виходу за межі набутих інтелектуальних стандартів.

2. Адекватність умов виконання наукового дослідження. Цей принцип передбачає, що університет повинен забезпечити відповідні умови для виконання наукових досліджень, які $є$ фундаментом реалізації та перевірки наукової гіпотези. За цих умов молодому вченому надаються повноваження самостійності та незалежності, він несе відповідальність за вибір та втілення наукового проекту [4].

3. Стимуляція міждисциплінарних досліджень передбачає відкритість дослідницького простору i культури з вивченням суміжних дисциплін.

4. Зв'язок з промисловістю та іншими секторами зайнятості. У контексті медичної післядипломної освіти цей принцип багатогранний і спрямований на впровадження нових наукових знань у суспільство, систему організації охорониздоров'я, інститути культури, бізнес. Він може реалізуватися у формі сумісного фінансування в організації тренінгів, запрошення вчених з інших вузів та спеціалістів з маркетингу, психології тощо до інформування, навчання та контролю ефективності набутих навичок та вмінь, фінансової підтримки тієї чи іншої галузі докторської програми, а також трансферу у системі “людина-технології-знання" [9].

5. Принцип інтернаціоналізації. На сьогодні європейський рівень докторської підготовки передбачає надання PhD-студентам можливостей для міжнародного співробітництва і комунікації за рахунок спільних досліджень, навчання чи стажування. Це, з одного боку, стимулює мобільність PhD-кандидатів, а з іншого - сприяє глобалізації досліджень. Як правило, європейські PhD-програми розраховані на участь 2-3 вузів у навчанні та виконанні наукових проектів молодих дослідників [1].

6. Акцент не тільки на знаннях, а й на навичках. На сьогодні у європейських і американських вузах ключова перевага віддається навичкам трансферу. Цей термін, тобто впровадження та використання отриманих під час освіти та дослідження нових знань i вмінь в інших галузях - наприклад, у сфері охорони 
здоров’ я, бізнесі, соціальному секторі й потребують певного досвіду. Сюди ж відносять навички комунікації, спільної (командної) роботи, керування проектами, інтелектуальної власності, етики, стандартизації тощо.

7. Забезпечення якості. Передбачає атестацію та оцінку якості не тільки освітньої програми, а й наукового дослідження. Останнє враховує оцінку якості умов виконання та достовірність результатів роботи, прозорість та повну звітність - від планування до завершення наукового проекту [10].

8. Забезпечення відповідного фінансування. Найбільш частим джерелом фінансування наукових проектів Свропи є національні та міжнародні гранти, мобілізацією яких займаються спеціальні відділи університетів. I саме відповідальні виконавці - учасники грантів - $є$ керівниками - супервайзерами, які визначають об'єм та склад дослідницької групи. 3

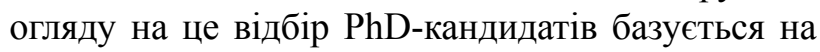
жорсткому конкурсі за інтелектуальними та професійними критеріями.

Звісно, що визначення європейських принципів та перспектив потребує певної адаптації до українських умов та законодавства. Ретельний аналіз європейських принципів підготовки науково-педагогічних кадрів через призму законів України разом із визначенням права університету на автономність та розробку власних освітніх програм привели до реорганізації системи підготовки наукових кадрів у ДонНМУ. Остання включає зміни у вузлових ланках: умови прийому; умови навчання; тренінги для відпрацювання навичок та вмінь, що відповідають кваліфікаційним вимогам наукових співробітників; система акредитації та контролю якості наукових досліджень; умови фінансування; стимуляція мобільності аспірантів. Звісно, що розроблена модель ще далека від ідеалу та повноцінного втілення. Проте навіть перші кроки у цьому напрямку дали певні плоди. Так, відзначено тенденцію зростання попиту до навчання в аспірантурі, прийом до якої за останній рік зріс на 30 \%. Звісно, що більш об' єктивним критерієм привабливості аспірантури є кількість аспірантів, що навчаються за контрактом. Саме тому університет в першу чергу зробив акцент на підвищення якості освітньої програми як передумови конкурентоспроможності у сфері надання освітніх послуг. 3 цією метою було запроваджено багаторівневу програму навчання, що відбиває сучасні досягнення світової науки та відповідає потребам самих аспірантів.

Проведене опитування молодих вчених ДонНМУ продемонструвало, що українська молодь достатньо інформована щодо існуючих систем $\mathrm{PhD}$ підготовки у вузах Свропи і вважає ці системи більш ефективними і привабливими, ніж існуюча модель аспірантури в Україні. Отримані результати опитування обгрунтували суттєві зміни переліку та змісту освітньої програми 3 переходом від стандартного набору “філософія, інформатика та іноземна мова” до гнучкої системи багаторівневого навчання протягом усієї аспірантури. Розроблена у ДонНМУ програма аспірантури включає обов' язкову та варіативні тематичні програми. До складу обов’язкової програми, окрім загальноосвітніх дисциплін (філософія, іноземна мова) і спеціальності, входить базовий методичний курс. Він включає вивчення біостатистики, етики та методології наукового дослідження, проходження тренінгів 3 відпрацювання навичок роботи з інформаційними ресурсами, планування наукових проектів, підготовки публікацій, презентації та впровадження наукових даних, стимуляції мовних та комунікаційних здібностей. Варіативні програми були створені на основі аналізу наукових інтересів молодих дослідників за принципом мультидисциплінарності. Обов'язковим елементом запровадження варіативних освітніх програм стало запрошення провідних вчених України і Росії 3 відповідних галузей науки, а також використання новітніх освітніх технологій.

Висновки. Реорганізація системи підготовки наукових кадрів, що проводиться у ДонНМУ, дозволяє не тільки засвоїти навички наукового дослідження як професії, поглибити та розширити компетенції науково-педагогічних робітників, а й отримати систему сучасної освіти, відкритої для впровадження нових знань та технологій. Звісно, що незважаючи на значну роботу, проведену у напрямку реорганізації системи аспірантури, ще залишається широке коло питань, які потребують серйозного вивчення. Зокрема: Чим визначається кількість місцьь та принципи планування прийому до аспірантури? Чи можна вважати можливою та якісною підготовку наукових кадрів поза аспірантурою? Як вирішити питання адекватного фінансування наукових проектів та розвитку матеріально-технічної бази університету? Скільки коштуватиме навчання на контрактній формі навчання в аспірантурі та яким має бути порядок використання цүих коштів? Яким чином стимулювати прогрес щзодо повноиінної участі університету у міжннародних освітніх та наукових програмах та проектах?

Усі ці питання потребують ретельного обговорення і чекають на відповіді. Проте... все, що мислимо, може бути здійснено. 


\section{Лiтература}

1. Bologna Seminar on "Doctoral Programmes for the European Knowledge Society" (Salzburg, 3-5 February 2005).

2. Declaration of Helsinki. - http://www.etikkom.no/ retningslinjer/helsinkideklarasjonen

3. European University Association. - http://www.eua.be

4. Guidelines for Research Ethics in Science and Technology / The National Committee for Research Ethics in Science and Technology (NENT), May 8th 2007.

5. Guidelines for research ethics in the social sciences, law and the humanities. - http://www.etikkom.no/English/NESH/ guidelines

6. Organisation for $\mathrm{PhD}$ Education in Biomedicine and Health Sciences in the European System. - www.orpheus-med.org

7. Second European Conference on Harmonisation of PhD Programmes in Biomedicine and Health Sciences, Zagreb, April 22-24, 2005.
8. Standards for PhD Education in Biomedicine and Health Sciences in Europe. ORPHEUS/AMSE/WFME Task Force.Aarhus University Press, Denmark 2012. - http:// www.orpheus-med.org/images/stories/documents/ ORPHEUS-AMSE-WFME-standards-for-PhD-education.pdf 9. Stefaan Hermans Researchers: Outcome of the consultation and Key Messages / ERA conference 2012, Brussels, January, 2012. - http://ec.europa.eu/research/era

10. The 7th ORPHEUS Conference "Establishing Evaluation of PhD Training", Bergen, Norway, 19-21 April 2012. - http:// www.orpheus2012.org/en/scientificprogrammespeakers

11. The Association of Medical Schools in Europe. www.amse-med.eu

12. World Federation for Medical Education. www.wfme.org 